\title{
Transcriptome and expression analysis of Sogatella furcifera (Horváth) (Hemiptera: Delphacidae) in response to cycloxaprid
}

\author{
Jin Jian Xue ( $\nabla$ jinjianxue163@163.com ) \\ Ye Zhao-Chun \\ Institute of Plant Protection Guizhou \\ Cheng Ying \\ Institute of Plant Protection Guizhou \\ Li Feng-Liang \\ Institute of Plant Protection Guizhou \\ Li Wen-Hong \\ Institute of Plant Protectiion Guizou \\ Zhou Yu-Hang \\ Institute of Plant Protection Guizhou \\ Jin Dao-Chao \\ Guizhou University
}

Institution of Plant Protection https://orcid.org/0000-0002-3016-5207

\section{Research article}

Keywords: Sogatella furcifera (Horváth); cycloxaprid; insecticide resistance; transcriptome; expression analysis

Posted Date: May 14th, 2019

DOI: https://doi.org/10.21203/rs.2.9592/v1

License: (1) (1) This work is licensed under a Creative Commons Attribution 4.0 International License. Read Full License 


\section{Abstract}

Background The white backed planthopper, Sogatella furcifera (Horváth), causes substantial damage to many crops by direct feeding or transmitting plant viruses, especially southern rice black-streaked dwarf virus (SRBSDV) that has become a great threat to rice production in East Asia. Cycloxaprid, a novel cisnitromethylene neonicotinoid insecticide, has good industrialization prospects because of its high efficiency against rice planthoppers, including imidacloprid-resistant populations. This chemical would be used extensively in future. However, very little is known about the influence on S. furcifera after cycloxaprid application at the molecular level. We sequenced S. furcifera transcriptome of female adult of $\mathrm{S}$. furcifera using the Illumina sequencing. Results By de novo transcriptome assembling and massive parallel pyrosequencing, we constructed two transcriptomes of S. furcifera and profiled the alternation of gene expression in response to cycloxaprid treatment in transcriptional level. Over 157,906,456 nucleotides and 131,601 different unigenes were generated using Illumina technology from both cycloxaprid-treatment and no-treatment S. furcifera. And a total of 38,534 unigenes matched known proteins in at least one database, accounting for $29.28 \%$ in total unigenes. The number of Coding DNA Sequence (CDS) were 28,546 and that of the amino acid sequence of coding region were 22,299. A total 15,868 simple sequence repeats (SSRs) were identified. The trinucleotide repeats accounted for $45.1 \%(7,157)$ in total SSRs and the (AAG/CTT)n was the most frequent motif. There were 359 differentially expressed genes (DEGs) that might be induced by cycloxaprid. There were 131 genes up-regulated and 228 down-regulated. 22 unigenes may take participate in the resistance to cycloxaprid, such as cytochrome P450, Glutathione-s transferase (GST), Acid phosphatase (ACP), cadherin, etc. Conclusions Our study will provide a splendid database for future investigations of the resistance mechanism induced by cycloxaprid and will provide new strategies for pest management and crop protection.

\section{Background}

Cycloxaprid, which firstly reported in 2008, patented and developed in China and first named in 2011[1-3]. Its action mode was known as targeting insect nicotinic acetylcholine receptors (nAChRs) and was similar to that of imidacloprid and nitenpyram but cycloxaprid has already been proven more effective than three other neonicotinoids: imidacloprid, thiamethoxam and nitenpyram for the control of piercing and sucking insect pests (aphids, leafhoppers, whiteflies, planthoppers etc), especially Sogatella furcifera in future[4][5]. As an oxabridged cis-configuration neonicotinoid insecticide, cycloxaprid has been considered a substitute for imidacloprid, especially the management of imidacloprid-resistant insects because it has performed well in controlling a broad spectrum of insect pests and has low toxicity for mammals[6][7].

S. furcifera (Horváth), the whitebacked planthopper, is one of most destructive migratory pests around Asia [8-10]. Its distribution areas include south and south-east Asia countries, China, korea, Japan, northern Australia and south Pacific Islands[11][12] and causes damage by directly feeding and ovipositing on rice stems. Moreover, it is an important vector transmitting several rice viruses, especially the southern rice black streaked dwarf virus (SRBSDV) causing enormous loss of rice yield [13-17]. 
The ecological , toxicological and physiological perspectives of $S$. furcifera and other hemipteran insect pests, such as Nilaparvata lugens, Laodelphax striatellus and Bemisia tabaci have been extensively studied[18-24]. Transcriptomes of Nilaparvata lugens and Laodelphax striatellus were reported using nextgeneration DNA sequencing techniques[25][26], and that responsed to SRBSDV[16]and to high and low doses of cycloxaprid[4] had also been studied. Furthermore, the olfactory receptor gene family[27] and the salivary glands[28] of $S$. furcifera had been sequenced, ect. The possible factors related to cycloxapridresistance and related genes by insecticide applications had been conducted. By treated with a low-dose and a high-dose treatment, these findings, based on transcriptome, showed that CYP4, CYP6, and GSTd contributed significantly to insecticide detoxification resistance[4]. However, it is little known to the whole transcripts and unigenes change after treated with cycloxaprid, In this study, hence, we constructed two transcriptomes of $S$. furcifera and profiled the alternation of gene expression in response to cycloxaprid induction at the transcriptional level. As a whole, 131,601 unigenes have been identified and 359 DEGs have been discovered.

\section{Results}

\section{Bioassay}

By bioassay, the LC10 and LC50 concentration of cycloxaprid-treatment was established. Regression equation was $y=0.97 x+3.9462(x 2=0.814, R=0.9835, P=0.6656>0.05), L C 10=0.5823 \mathrm{mg}(L-1[95 \%$ confidence interval $(\mathrm{Cl}), 0.1289-1.2322]$ and $\mathrm{LC} 50=12.2011 \mathrm{mg}(\mathrm{L}-1$ [95\% Cl, 6.4689-37.1984].

\section{RNA isolation}

The values of Optical Density (OD260/280) ranges from 1.962 to 2.005 , the RNA integrity number (RIN) value of six samples were larger than 7.0, indicating that they were pure and not degraded. So, the Ribonucleic Acid (RNA) quality of all samples meet the requirements of sequencing.(Table 1)

\section{Transcriptome Assembly of S. furcifera}

The $S$. furcifera transcriptomes were generated from 5 female adults emerged in $48 \mathrm{~h}$ after treated by cycloxaprid LC10 concentration (HYFA) and 5 no-treatment female adults (CKFA) via the Illumina sequencing. Three replicates were prepared. We then constructed a mass gene database that contains a total of 157,906,456 nucleotides (nt). After eliminating low quality reads from the raw reads, there were $45,934,376$ average clean reads remained in cycloxaprid-treatment, which accounted for $96.00 \%$ of the raw reads and $42,495,937$ average clean reads remained in no-treatment, which accounted for $93.90 \%$ of their raw reads. The short reads assembly software Trinity was used to assemble, compare and ligate all clean data so as to get the unigenes from the $S$. furcifera transcriptome. These reads were assembled into 131,601 unigenes, the mean length is $720 \mathrm{bp}$. The $67.38 \%$ of unigenes ranged from $200-500 \mathrm{bp}$ and $15.28 \%$ of unigenes ranged from $500-1000 \mathrm{bp}$. The $17.33 \%$ of unigenes ranged from more than $1000 \mathrm{bp}$ in length. (Figure 1,Table 2, 3) 
The results of unigenes functional annotation by non-redundant protein sequences (NR), Gene Ontology (GO), euKaryotic Ortholog Groups (KOG) and kyoto Encyclopedia of Genes and Genomes (KEGG), etc were showed in Table 4.

A total of 26,204 unigenes returned an above cut-off blast hit to NR database of the National Center for Biotechnology (NCBI), which account to $19.91 \%$ of 131,601 unigenes from the $S$. furcifera transcriptome. The species distribution of the top blastx hits for each unique sequence was shown in Figure 2. The unambiguous assembled sequences revealed that the percentage of matches sequences was $15.3 \%$ from zootermopsis nevadensis, followed by Acyrthosiphon pisum (5.2\%), Tribolium castaneum (4.7\%), and the greatest number of no-matches was $67.8 \%$.

Based on the $S$. furcifera transcriptome assembly, 27,079 (20.57\%) sequences were annotated in the GO database, which were divided into a total of 49 groups in three ontology categories (biological process, cellular component, molecular function). The "biological process" ontology category contains 24 groups. The largest group is "cellular process" with 15,163 unigenes, followed by "metabolic process" with 14,033 unigenes and the smallest group is "rhythmic process" with 30 unigenes. The "cellular component" ontology category contains 17 groups. The largest groups are "cell" and "cell part" with the same numbers, 8,460 unigenes, respectively. And the smallest group is "extracellular matrix component" with only four unigenes. The "molecular function" ontology category contains 8 groups. The largest group is "binding" with 14,136 unigenes, and the smallest group is "transcription factor activity, protein binding" with 314 unigenes (Figure $3)$.

In order to annotate the detail function of genes, KOG database was used. In total, 15,447 unigenes $(11.76 \%)$ were annotated and these genes were divided into 26 categories. and a total of 3,104 unigenes (20.06\%) were placed into the "General function prediction only" category. Followed by "signal transduction mechanisms" $(1,986,12.83 \%)$, "posttranslation modification, protein turnover, chaperones" $(1,585,10.24 \%)$, and the smallest category is "Cell motility" with 21 unigenes. There are three unigenes annotated "Unamed protein", accounting for only $0.02 \%$ of the functionally annotated unigenes.(Figure 4 )

To identify the genes that involved in metabolic pathways, a total of 15,058 unigenes (11.44\%) were mapped to the KEGG pathway database. These unigenes were divided into 32 pathways. The largest pathway is "signal transduction" with 1,829 unigenes (15.98\%). Followed by "endocrine system" with 1,089 unigenes $(9.52 \%)$. The smallest pathway is "Biosynthesis of other secondary metabolites" with only 33 unigenes $(0.2 \%)$. (Figure 5$)$.

To validate the transcriptome, we compared the expression profiles of the cycloxaprid-treatment and notreatment using qRT-PCR. We selected 18 unigenes randomly, Primers used in qRT-PCR for validation of DEGs were shown in Table 5. 14 of which demonstrated a concordant direction of change and 4 unigenes were inconsistent between transcriptome and qRT-PCR (Table 6). The results indicated that our results are reliable.

\section{SSRs detection analysis}


By using $S$. furcifera transcriptome sequences, we have identified 15,868 SSRs. According to predictions, about $10.56 \%$ of protein-coding sequences possessed such repeats, of which $45.1 \%$ were trinucleotide repeats, with (AAG/CTT)n being the most frequent motif (43.13\%), followed by $36.82 \%$ mononucleotide, $16.49 \%$ dinucleotide, $1.42 \%$ tetranucleotide, $0.107 \%$ pentanucleotide, $0.063 \%$ hexanucleotide repeats (Figure 6). These results are confirmed with these reports showing that trinucleotide repeats (AAG/CTT)n are the most generous microsatellites in coding ESTs [16][29][30]. Similarly, Xu(2012) also reported that (AAG)n was the most frequent motif (39.8\%) in S. furcifera[16]. However, it had been confirmed by the former work that (AAC)n is the most frequent motif in the small brown planthopper (L. striatellus) [26]. The difference of predicted trinucleotide repeats in the two transcriptomes may give an expression on distinct adaptability of these insects. The numerous potential molecular markers gained from our study would play a particularly important role on genetic mapping, genotyping and parentage analysis of these insect species[16].

\section{Identification of DEGs}

To identify DEGs, the numbers of clean reads for each gene were counted, then individual sets of reads were mapped back to the previously assembled transcript and counted as a proxy for gene expression. DESeq[31] was used to identify the differentially expressed transcripts between the two samples (HYFA and CKFA), padj<0.05 (with biological replicates). The numbers of up-regulated genes was 131 and downregulated was 228 , in total 359 DEGs (Figure 7).

217 DEGs were annotated in the GO database, inluding 65 up-regulated genes, which was approximatelty half of the 131 genes, and 152 down-regulated, which accounted to $66.67 \%$ of the 228 genes. These DEGs were assigned into groups according to these genes functions, biological process, cellular component and molecular function, and in the biological process, the largest groups were annotated into the "phosphorylation" and "protein phosphorylation". In the "cellular component" ontology category, the main groups are showed in Figure 8. The largest group of the "molecular function" ontology category is "catalytic activity".

The DEGs were mapped to the KEGG pathway database, which involved in metabolic pathways, These genes were divided into 179 pathways. The largest pathway is "Pathways in cancer" with 59 unigenes. Followed by "Proteoglycans in cancer" with 40 unigenes. "Rap1 signaling pathway" with 38 genes and "Prostate cancer" with 37 genes (Figure 9).

\section{Identification of unigenes and DEGs related to insecticide-resistance}

In all unigenes of the $S$. furcifera transcriptome, by these keywords related with insecticide resistance, we could found some metabolic resistance genes, 237 cytochrome P450 genes, 48 glutathione -s transferases (GSTs), 19 carboxylesterases (CarE), and target-site resistance genes, including 17 nicotinic acetylcholine receptor (nAChRs), 37 y-aminobutyric acid receptors (GABA receptors), 50 acetylcholinesterase (AchEs), 99 sodium channels, etc (Table 7).

Based on the annotation results of basedata, we identified 3 categories of genes that associated with metabolic resistance, 2 Cytochrome P450s and 2 GSTs and target-site resistance, 1 Cadherin, etc in 359 


\section{Conclusion}

In this study, we obtained 131,601 unigenes with mean lengths of $720 \mathrm{bp}$, which are a major genomic resource for clarifying the genes expression induced by cycloxaprid in S. furcifera. A total of 29,326 unigenes matched known proteins in the NCBI database. A total 15,868 simple sequence repeats were identified. 359 differentially expressed genes could be related with the cycloxaprid-induction in S. furcifera. And 22 unigenes may associated with cycloxaprid. such as cytochrome P450, GST, ACP, cadherin, etc.

\section{Discussion}

Insect resistance to insecticides generally related to each of three main mechanisms: lower epidermal tissue penetration; metabolic resistance[32], which include the over-expression or detoxification of some critical enzymes, such as cytochrome P450[4][33][34], esterase and GST[35]. And target-site resistance, such as GABA receptor[36], AChE, sodium channel[37] etc.

Cytochrome P450 superfamilies were universal and constituted by many complex members, including 70 families, with 127 subfamilies, of hydrophobic, hemecontaining enzymes. P450s are involved in the biosynthesis of several essential endogenous compounds and the detoxification of many xenobiotics[38] [39]. In insects, P450s are induced by a wide range of inducers[40] and could mediate resistance to all classes of insecticides[41]. And overexpression of P450 genes has been reported to be related with development of insecticide resistance in many insect species, such as Nilaparvata lugens (Stål) to imidaclorprid[33][42], Laodelphax striatellus (Fallen) to ethiprole[43], Musca domestica to phenobarbital[39], Anopheles gambiae[44][45] and Meligethes aeneus Fabricius[35] to pyrethroids, etc. More than half of the P450 genes belong to either the CYP4 or CYP6 families[46][47]. The CYP4 family includes sequences from vertebrates and are involved in hydroxylations of steroids, fatty acids and prostaglandins[48], whereas CYP6 enzymes, insect specific, appear to be involved in the metabolism of xenobiotics and plant products, e.g., pyrethroids and furanocoumarins[49]. In our study, only 2 P450 genes from DEGs were annotated as 1 CYP 4 family and 1 CYP 6 family.

Glutathione -s transferases (GSTs) contain many multifunctional detoxification enzymes and are indispensable in the process of insecticides metabolism, especially organophosphorus insecticides[50]. GSTs could catalyzed the conjugation of reduced glutathione (GSH) with electrophilic endogenous and xenobiotic compounds and end products of lipid peroxidation[51]. The increased expression and activity of GSTs has been clarified as one of mechanisms of insect resistance[52][53]. GSTs have been known to confer resistance to organochlorine, organophosphorous and pyrethroid, such as mosquitoes to DDT[54] [55], Musca domestica L. to diazinon, parathion and diazoxon [56], Plutella xylostella to methyl parathion[57], Spodoptera litura to Chlorpyrifos[58], Nilaparvata lugens to permethrin and lambdacyhalothrin[59][60], Nilaparvata lugens to pyrethroid[60], Bombyx mori to fenpropathrin[61], Leptinotarsa decemlineata to cyhalothrin, fipronil and endosulfan [62], etc. In the study, 48 unigenes in the S. furcifera transcripome belong to GSTs, but only two DEGs code glutathione -s transferase were identified. 
Phosphatases, including acid and alkaline phosphatases(ACP and ALP), are capable of hydrolysis and transphosphorylation. They are important in the metabolism of carbohydrates, phospholipids and nucleotides and have been reported as enzymes significant in resistance to insecticides. ACP belongs to a group of enzymes that hydrolyze phosphomonoesters at acidic $\mathrm{pH}[63]$ and occupies a significant position in the detoxification of toxic compounds entering the body, acts as an enzymatic defence against foreign compounds and plays an essential role in maintaining normal physiological functions[64-68]. In the study, only one gene was founded to code acid phosphatases in 359 DEGs.

Cadherins represent a large and complicated family of calcium-dependent, transmembrane glycoproteins and a cytoplasmic tail that binds catenins which support to link the cadherin to the actin cytoskeleton, as well as also function in cellular signaling[69-72] and are responsible for maintaining the integrity of cell-cell contacts in multicellular organisms. In addition, cadherins include a class of proteins which were known to be related with Bt Cry protein binding and toxicity to Lepidoptera, Diptera and Coleoptera insects[73][74], and have been identified in other invertebrates as crucial target receptors for Cry toxins[75-77]. Plutella xylostella was the first insect species which reported to evolve resistance to Bt in field populations[78] and its high resistance levels to Bt have been confirmed with the loss of binding affinity of Cry toxins to their protein receptors, including cadherin, on the midgut brush border membrane[79][80]. Vadlamudi et al reported that a cadherin localized in the midgut epithelium of Manduca sexta serves as the receptor for Cry1A toxins of Bacillus thuringiensis[81][82]. Gahan et al.(2001) showed that the resistance to Cry1Ac toxin in Heliothis virescens is associated to retrotransposon-mediated disruption of a specific cadherin gene. Moreover, confirmed that midgut epithelial cadherins participated directly in the entomopathogenicity of $B$. thuringiensis[76]. However, there is little evidence that cadherin was related with the resistance to other insecticides beside Cry toxins. In our study, only one gene from DEGs could code cadherin.

\section{Methods}

\section{Insects and Insecticides}

S. furcifera were collected from Huaxi district of Guiyang in Guizhou Province, China in July 2014 and bred down 20 generations under condition as hereinafter. The insects were reared on 10 day old rice seedlings cultured in plastic boxes $(34 \times 23.5 \times 20 \mathrm{~cm})$ at $25 \pm 1^{\circ} \mathrm{C}$ temperature, $50 \%$ to $60 \%$ relative humidity, and L16:D8 $\mathrm{h}$ photoperiod in constant-temperature incubator[83].

Technical grade: cycloxaprid (97\%) was provided by Shengnong pesticide Co., Ltd. Shanghai, China.

\section{Bioassay}

The rice-stem dipping method [22][84][85] was used for the dose-responses of $S$. furcifera to cycloxaprid. Cycloxaprid was firstly dissolved into mother liquid by acetonitrile plus 10\% Triton-100 (m/V; Solarbio Science \& Technology Co., Ltd. Beijing, China) as an emulsifer. Then the mother liquid were serially diluted into 5-9 different concentrations with distilled water, respectively. The mortality was recorded $96 \mathrm{~h}$ later for cycloxaprid. The nymphs were considered dead if they failed to move when gently prodded with a fine bristle. The mortality data were corrected by the control mortality using Abbott's formula. Regression 
equation (LC-P line) $\square$ LC50 values (mg-L-1) $₫ 10 \%$ lethal concentration(LC10) and 95\% confidence interval (Cl) etc were calculated by using Data Processing System (DPS ver. 8.05) software (Hangzhou RuiFeng Information Technology CO., LTD. Hangzhou, China)[83][86].

\section{Sample collection and preparation}

The mother liquid of cycloxaprid was diluted into $1 \times$ LC10 concentration and distilled water was used as the control. The rice seedlings were dipped into these solution for 30 s, respectively. More than one hundred of the fifth instar nymphs were introduced on these treated rice seedlings when air-dried at room temperature. After 48h treated, emergency adults would be distinguished between male and female and collected in EP tubes, respectively. Then, 48h, 5 female adults (HYFA) were randomly sellected for subsequent RNA isolation, transcriptome sequencing. Three replicates were prepared (plus the control (no-treatment) (CKFA) in total 30 nymphs). All collected bodies were immediately frozen by liquid nitrogen and stored at $-80^{\circ} \mathrm{C}$ until use[83].

\section{RNA isolation, Library construction}

Qubit ${ }^{\circ}$ RNA Assay Kit (Life Technologies, CA, USA) was used to measure RNA concentration. 1\% agarose gels was used to monitor RNA degradation and contamination. The NanoPhotometer® spectrophotometer (IMPLEN, CA, USA) was used to check the RNA purity. The RNA Nano 6000 Assay Kit of the Agilent Bioanalyzer 2100 system (Agilent Technologies, CA, USA) was used to assess RNA integrity.

Transcriptome sequencing of S. furcifera was finished by Beijing Novogene Bioinformatics Technology Co., Ltd (Beijing, China).

$1.5 \mu \mathrm{g}$ total RNA for each sample was used for the RNA sample preparations. NEBNext® Ultra ${ }^{\mathrm{TM}}$ RNA Library Prep Kit for Illumina ${ }^{\circledR}$ (NEB, USA) was used to generate sequencing libraries. OligoT attached magnetic beads was used to enrich mRNA from total RNA. Then, mRNA was interrupted into short fragments via adding fragmentation Buffer (5X). Random hexamer primer and M-MuLV Reverse Transcriptase (RNase H-) was used to synthesize the first strand cDNA. Subsequently, DNA Polymerase I, RNase H, dNTPs and Buffer were used to synthesize the second strand cDNA. Polymerase could converted the remaining overhangs into blunt ends. The double strand cDNA were purified with AMPure XP beads. After adenylation of 3' ends of DNA fragments, NEBNext Adaptor with hairpin loop structure were ligated to prepare for hybridization. After terminal repaired and plus A-tail and sequencing connector, the library fragments were purified with AMPure XP system (Beckman Coulter, Beverly, USA) so as to select cDNA fragments of 150-200 bp in length preferentially. Subsequently polymerase chain reaction (PCR) was performed with T100 thermal cycler PCR Instrument (Bio-rad, USA) and then PCR products were purified with AMPure XP system. Finally, library quality (insert size) was assessed on the Agilent 2100 system and effective concentration of the library was analysized with Q-PCR (>2nM). Illumina Hiseq platform was used to sequence the library and generate the paired-end clean reads. TruSeq PE Cluster Kit v3-cBot-HS (Illumia) was used to perform the clustering of the index-coded samples on a cBot Cluster Generation System. 
Two transcriptomes of $S$. furcifera were constructed treatment by cycloxaprid (HYFA) and no-treatment (CKFA)[83].

\section{Data analysis}

\section{Quality control}

Raw data (raw reads) of fastq format were firstly processed through in-house perl scripts. In this step, excluding reads containing adapter, ploy- $\mathrm{N}$ and low quality reads from raw data, clean reads with high quality were obtained so as to subsequent analysis, Q20, Q30, GC-content and sequence duplication level of the clean reads calculated. All the downstream analyses were based on clean data with high quality[83].

\section{Transcriptome assembly}

The left files (read1 files) from all libraries/samples were pooled into one big left.fq file, and right files (read2 files) into one big right.fq file. Transcriptome assembly was accomplished based on the left.fq and right.fq using Trinity[87] with min_kmer_cov set to 2 by default and all other parameters set default.

Gene function was annotated based on the following databases: NR (Non-Redundant protein sequences) $\bigotimes$ NT (Non-Redundant nucleotide sequences) $\triangle P f a m$ (Protein family) $\triangle K O G$ (euKaryotic of Orthologous Groups of proteins) $₫$ Swiss-Prot (A manually annotated and reviewed protein sequence database) $₫$ KEGG (Kyoto Encyclopedia of Genes and Genomes ) $\mathbb{G O}$ (Gene Ontology)[83].

\section{SSR detection and primer design}

SSR of the transcriptome were identified using MISA (http://pgrc.ipk-gatersleben.

de/misa/misa.html), and primer for each SSR was designed using Primer 5.

\section{Differential expression analysis}

RSEM were used to estimate gene expression levels[88] for each sample. For the samples with biological replicates, the DESeq R package (1.10.1) was used to perform the differential expression analysis of two groups (HYFA and CKFA). The Benjamini and Hochberg's approach was used to modify the resulting $P$ values for controlling the false discovery rate. Genes with an adjusted P-value $<0.05$ was set as the threshold for obviously differential expression.

To verify the accuracy of the transcriptome, the expression levels of 18 genes were conducted by qRT-PCR. Total RNAs from each sample were extracted using Triozol RNA (Life Technology) and treated with DNase I (Invitrogen) according to the manufacturer's protocol. The concentration of each RNA sample was adjusted to $1 \mathrm{mg} / \mathrm{mL}$ with nuclease-free water and total RNA was reverse transcribed in a 20ul reaction system using the BestarTM qPCR RT Kit (DBI). qRT-PCR was carried out on the Bestar® SybrGreen qPCR mastermix (DBI, Germany) under the following conditions: $95^{\circ} \mathrm{C}$ for $2 \mathrm{~min}$; and 45 cycles of $95^{\circ} \mathrm{C}$ for $10 \mathrm{~s}, 60^{\circ} \mathrm{C}$ for $34 \mathrm{~s}$, and $72^{\circ} \mathrm{C}$ for $30 \mathrm{~s}$, followed by melting curve generation $\left(60^{\circ} \mathrm{C}\right.$ to $\left.98^{\circ} \mathrm{C}\right)$. Each gene was analyzed in triplicates, after which the average threshold cycle (CT) was calculated per sample, and an endogenous 18SrRNA gene 
(GenBank accession number: AB625607) of $S$. furcifera was used for internal normalization. A control sample without template was used to monitor contamination and determine the degree of dimer formation in the process of experiment[83].

\section{Abbreviation}


SRBSDV The southern rice black-streaked dwarf virus

S. furcifera Sogatella furcifera (Horváth)

CDS Coding DNA Sequence

SSRs Simple Sequence Repeats

\begin{tabular}{ll} 
DEGs & differentially expressed genes \\
GST & Glutathione-s transferase \\
ACP & Acid phosphatase \\
\hline nAChRs & nicotinic acetylcholine receptors
\end{tabular}

CarE Carboxylesterases

GABA $\quad y$-aminobutyric acid receptors

receptors

AchEs Acetylcholinesterase

ACP Acid Phosphatase

DNA deoxyribonucleic acid

CYP4 Cytochrome P450 4 family

CYP6 Cytochrome P450 6 family

LC10/50 Lethal Concentration

$\mathrm{Cl} \quad$ Confidence Interval

OD optical density

RIN RNA integrity number

RNA ribonucleic acid

PCR polymerase chain reaction

cDNA complementary DNA

bp base pairs

nt nucleotides

dNTP deoxyribonucleoside triphosphate

NR non-redundant protein sequences

NT nucleotide sequences

Pfam protein family 


\begin{tabular}{ll} 
KOG & euKaryotic Ortholog Groups \\
\hline KEGG & kyoto Encyclopedia of Genes and Genomes \\
\hline GO & Gene Ontology \\
\hline FPKM & $\begin{array}{l}\text { expected number of Fragments Per Kilobase of transcript sequence per Millions base } \\
\text { pairs sequenced }\end{array}$ \\
\hline mRNA & messenger ribonucleic acid \\
\hline NCBI & national center for biotechnology \\
\hline qRT-PCR & Quantitative Real-time PCR \\
\hline ESTs & Expressed Sequence tags \\
\hline M & molarity \\
\hline h & hour \\
\hline min & minute \\
\hline mg & milligram \\
\hline ml & milliliter \\
\hline$\mu l$ & microliter \\
\hline sec & second \\
\hline EP & eppendorf tube \\
\hline g & gravity \\
\hline $16 L: 8 D$ & T6 Light:8 Dark \\
\hline FL & Fiducial limits \\
\hline USA & United States of American \\
\hline CA & California \\
\hline CT & The average threshold cycle \\
\hline
\end{tabular}

\section{Declarations}

\section{Ethics approval and consent to participate}

Not applicable.

\section{Consent for publication}

Not applicable. 
Data Availability Statement: All data generated or analysed during this study are included in this published article.

The data that support the findings of this study are available from NCBI SRA database(Accession number: SRR4294200 and SRR4294203), but restrictions apply to the availability of these data, which were used under license for the current study, and so are not publicly available. Data are however available from the authors upon reasonable request and with permission of NCBI SRA database.

\section{Competing Interests}

This manuscript and its authors are not involved in any potential conflicts of interest, including financial interests and relationships and affiliations.

\section{Funding}

This work was funded by the Guizhou Agricultural Science and Technology Project (NY[2013]3007) and the Provincial Outstanding Graduate Program for Agricultural Entomology and Pest Control (ZYRC-[2013]010). These projects provide financial support for this study.

\section{Authors' contributions}

Mrs. Jin JX analyzed and verified the transcriptome data of S. furcifera inducing by cycloxaprid and writed this manuscript. Mr. Ye ZC and Mrs. Cheng Y gave assistance in processing experimental data. Mrs. Li WH and Mr. Zhou YH provided help in rearing S. furcifera in our laboratory. Mr. Li FL and Jin DC were major contributors in amending this manuscript. All authors read and approved the final manuscript.

\section{Acknowledgments}

Acknowledge Mr. Su JY who provided many study opportunities to his laboratory in Nanjing agricultural university and provided professional ideas and recommendations.

\section{References}

[1] Shao XS, Zhang WW, Peng YQ, Li Z, Tian ZZ, Qian XH. cis-Nitromethylene neonicotinoids as new nicotinic family: synthesis, structural diversity, and insecticidal evaluation of hexahydroimidazo [1,2alpha]pyridine. Bioorg Med Chem Lett. 2008;18:6513-6516.

[2] Li C, Xu XY, Li JY, Ye QF, Li Z. Radiosynthesis of tritium-labeled novel nitromethylene neonicotinoids compounds with NaB3H4. J Labelled Compd Rad. 2011;54: 256-259.

[3] Pan HS, Liu YQ, Liu B, Lu YH, Xu XY, Qian XH, Wu KM, Desneux N. Lethal and sublethal effects of cycloxaprid, a novel cisnitromethylene neonicotinoid insecticide, on the mirid bug Apolygus lucorum. J Pest Sci. 2014;87:731-738. 
[4] Yang YX, Zhang YX, Yang BJ, Fang JC, Liu ZW. Transcriptomic Responses to Different Doses of Cycloxaprid Involved in Detoxification and Stress Response in the Whitebacked Planthopper, Sogatella Furcifera. Entomol Exp Appl. 2016;158: 248-257.

[5] Liu BS, Zhang ZC, Xie L, Zhang GF, Wang LH. Comparison of biological activity and field efficiency of cycloxaprid and other new neonicotinoid insecticides to rice planthoppers. Southwest China J Agri Sci. 2013;26:155-158.

[6] Shao XS, Fu H, Xu XY, Xu XL, Liu ZW, Li Z, Qian XH. Divalent and oxabridged neonicotinoids constructed by dialdehydes and nitromethylene analogues of imidacloprid: design, synthesis, crystal structure, and insecticidal activities. J Agr Food Chem. 2010;58:2696-2702.

[7] Shao X, Lee PW, Liu Z, Xu X, Li Z, Qian X. cis-Configuration: a newtactic/rationale for neonicotinoidmolecular design. J Agr Food Chem. 2011;59: 2943-2949.

[8] Kisimoto R. Long distance migration of planthopper, Sogatella furcifera and Nilaparvata lugens. Trop Agr Res Ser. 1971;5:201-216.

[9] Cheng J. Rice planthopper problems and relevant causes in China. In: Heong KL, Hardy B, editors. Planthoppers: New Threats to the Sustainability of Intensive Rice Production Systems in Asia. Philippines, Los Baños: International Rice Research Institute; 2009. p. 157-178.

[10] Sogawa K, Liu GJ, Qiang Q. Prevalence of whitebackedplanthopper in Chinese hybrid rice and whitebackedplanthopper resistance in Chinese japonica rice. In: Heong KL, Hardy B, editors. Planthoppers: New Threats to the Sustainability of Intensive Rice Production Systems in Asia, Philippines, Los Baños: International Rice Research Institute; 2009. p. 257-280 .

[11] Khan ZR, Saxena RC. A selected bibliography of the whitebacked planthopper, Sogatella furcifera (Horváth) (Homoptera: Delphacidae). Insect Sci Appl. 1985;6: 115-134.

[12] Matsumura M, Sanada-Morimura S, Otuka A, Ohtsu R, Sakumoto S, Takeuchi H., Satoh M. Insecticide susceptibilities in populations of two rice planthoppers, Nilaparvata lugens and Sogatella furcifera, immigrating into Japan in the period 2005-2012. Pest Manag Sci. 2013;70: 615-622.

[13] Zhang HM, Yang J, Chen JP, Adams MJ. A black-streaked dwarf disease on rice in China is caused by a novel fijivirus. Arch Virol. 2008;153:1893-1898.

[14] Zhou GH, Wen JJ, Cai DJ, Li P, Xu DL, Zhang SG. Southern rice black-streaked dwarf virus: a new proposed Fijivirus species in the family Reoviridae. Chin Sci Bull. 2008;53:3677-3685.

[15] Yin X, Xu FF, Zheng FQ, Li XD, Liu BS, Zhang CQ. Molecular characterization of segments S7 to S10 of a southern rice black-streaked dwarf virus isolate from maize in northern China. Virol Sin. 2011;26:47-53.

[16] Xu Y, Zhou WW, Zhou YJ, Wu JX, Zhou XP. Transcriptome and Comparative Gene Expression Analysis of Sogatella Furcifera (Horvath) in Response to Southern Rice Black-Streaked Dwarf Virus. PloS ONE. 
[17] Zhou GH, Xu DL, Xu DG, Zhang MX. Southern rice black-streaked dwarf virus: a white-backed planthopper transmitted Fiji virus threatening rice production in Asia. Front Microbiol. 2013;4:1-9.

[18] Mills AP, Rutter JF, Rosenberg LJ. Weather associated with spring and summer migrations of rice pests and other insects in south-eastern and eastern Asia. B Entomol Res. 1996;86: 683-694.

[19] Endo S, Tsurumach M. Insecticide susceptibility of the brown planthopper and the white-backed planthopper collected from Southeast Asia. J Pestic Sci. 2001;26:82-86.

[20] Otuka A, Matsumura M, Watanabe T, Van Dinh T. A migration analysis for rice planthoppers, Sogatella furcifera (Horvath) and Nilaparvata lugens (Stål)(Homoptera: Delphacidae), emigrating from northern Vietnam from April to May. Appl Entomol Zool. 2008;43:527-534.

[21] Wang YH, Chen J, Zhu YC, Ma CY, Huang Y, Shen JL. Susceptibility to neonicotinoids and risk of resistance development in the brown planthopper, Nilaparvata lugens (Stål) (Homoptera: Delphacidae). Pest Manag Sci. 2008;64:1278-1284.

[22] Zhang K, Zhang W, Zhang S, Wu SF, Ban LF, Su JY, Gao CF. Susceptibility of Sogatella furcifera and Laodelphax striatellus (Hemiptera: Delphacidae) to Six Insecticides in China. J Econ Entomol. 2014;107:1916-1922.

[23] Xie W. Liu Y, Wang SL, Wu QJ, Pan HP, Yang, X, Guo LT, Zhang YJ. Sensitivity of Bemisia tabaci (Hemiptera: Aleyrodidae) to several new insecticides in china: effects of insecticide type and whitefly species, strain, and stage. J Insect Sci. 2014; doi:10.1093/jisesa/ieu123.

[24] Caballero R, Cyman S, Schuster DJ. Monitoring insecticide resistance in biotype B of Bemisia tabaci (Hemiptera: Aleyrodidae) in Florida. Fla Entomol.2013;96:1243-1256.

[25] Xue JA, Bao YY, Li BL, Cheng YB, Peng ZY, et al. Transcriptome analysis of the brown planthopper Nilaparvata lugens. PLoS ONE. 2010;5:e14233.

[26] Qian W, Zhang FJ, Guo HY, Zheng HJ, Zhou T, et al. Massively parallel pyrosequencing-based transcriptome analyses of small brown planthopper (Laodelphax striatellus), a vector insect transmitting rice stripe virus (RSV). BMC Genomics. 2010;11:303.

[27] He M, Zhang YN, He P. Molecular characterization and differential expression of an olfactory receptor gene family in the White-Backed Planthopper Sogatella furcifera based on transcriptome analysis. PLoS ONE. 2015; doi:10.1371/journal.pone.0140605.

[28] Li Z, An XK, Liu YD, Hou ML. Transcriptomic and Expression Analysis of the Salivary Glands in WhiteBacked Planthoppers, Sogatella furcifera. PLoS ONE. 2016;11:e0159393. 
[29] Castagnone-Sereno P, Danchin EGJ, Deleury E, Guillemaud T, Malausa T, et al. Genome-wide survey and analysis of microsatellites in nematodes, with a focus on the plant-parasitic species Meloidogyne incognita. BMC Genomics. 2010;11:598.

[30] Groppe K, Sanders I, Wiemken A, Boller T. A microsatellite marker for studying the ecology and diversity of fungal endophytes (Epichloe spp.) in grasses. Appl Environ Microbiol. 1995; 61:3943-3949.

[31] Anders S, Huber W. Differential expression analysis for sequence count data. Genome Biol. 2010;doi:10.1186/gb-2010-11-10-r106.

[32] Li XC, Schuler MA, Berenbaum MR. Molecular mechanisms of metabolic resistance to synthetic and natural xenobiotics. Annu. Rev. Entomol. 2007;52: 231-253.

[33] Ding ZP, Wen YC, Yang BJ, Zhang YX, Liu SH, Liu ZW, Han ZJ. Biochemical mechanisms of imidacloprid resistance in Nilaparvata lugens: over-expression of cytochrome P450 CYP6AY1. Insect Biochem. Mol. Biol. 2013;43:1021-1027.

[34] Zimmer CT, Bass C, Williamson MS, Kaussmann M, Wölfel K, Gutbrodd O, Nauena R. Molecular and functional characterization of CYP6BQ23, a cytochrome P450 conferring resistance to pyrethroids in European populations of pollen beetle, Meligethes aeneus. Insect Biochem. Mol. Biol. 2014;45:18-29.

[35] Salinas AE, Wong MG. Glutathione S-transferases-a review. Curr. Med. Chem. 1999;6:279-309.

[36] Wondji CS, Dabire RK, Tukur Z, Irving H, Djouaka R, Morgan JC. Identification and distribution of a GABA receptor mutation conferring dieldrin resistance in the malaria vector Anopheles funestus in Africa. Insect Biochem. Mol. Biol. 2011;41: 484-491.

[37] Ranson H, Jensen B, Vulule JM, Wang X, Hemingway J, Collins FH. Identification of a point mutation in the voltage-gated sodium channel gene of Kenyan Anopheles gambiae associated with resistance to DDT and pyrethroids. Insect Mol Biol. 2000;9:491-497.

[38] Feyereisen R, Koener JF, Farnsworth DE, Nebert DW. Isolation and sequence of cDNA encoding a cytochrome P-450 from an insecticide-resistant strain of the house fly, Musca domestica. P Natl Acad Sci USA. 1989;86:1465-1469.

[39] Scott JG. Cytochromes P450 and insecticide resistance. Insect Bioche Molec. 1999; 29:757-777.

[40] Feyereisen R. Insect Cytochrome P450. In: Gilbert LI, latrou K, Gill SS, editors. Comprehensive Molecular Insect Science, vol. 4. Oxford, Elsevier; 2005.p.1-77.

[41] Daborn PJ, Lumb C, Boey A, Wong W, Batterham P. Evaluating the insecticide resistance potential of eight Drosophila melanogaster cytochrome P450 genes by transgenic over-expression. Insect Biochem Mol Biol. 2007;37:512-519. 
[42] Liu ZW, Han ZJ, Wang YC, Zhang LC, Zhang HW, Liu CJ. Selection for imidacloprid resistance in Nilaparvata Lugens: cross-resistance patterns and possible mechanisms, Pest Manag Sci. 2003;59: 13551359.

[43] Elzaki MEA, Zhang W, Han ZJ. Cytochrome P450 CYP4DE1 and CYP6CW3v2 contribute to ethiprole resistance in Laodelphax striatellus (Fallén). 2015;24:368-376.

[44] Nikou D, Ranson H, Hemingway J. An adult-specific CYP6 P450 gene is overexpressed in a pyrethroidresistant strain of the malaria vector, Anopheles gambiae.Gene. 2003;318;91-102.

[45] Constant VE, Luc D, Adam MJ, Kimberly R, Marc ATM, Rodolphe P, Christopher MJ, et al. CYP6 P450 enzymes and ACE-1 duplication produce extreme and multiple insecticide resistance in the malaria mosquito Anopheles gambiae. PIOS Genet. 2014;10:1-12.

[46] Tizet N, Helvig C, Feyereisen R. The cytochrome P450 gene superfamily in Drosophila melanogaster: annotation, intron-exon organization and phylogeny. Gene. 2001;262:189-198.

[47] Ranson H, Nikou D, Hutchinson M, Wang X, Roth W, et al. Molecular analysis of multiple cytochrome P450 genes from the malaria vector, Anopheles gambiae. Insect Mol Biol. 2002;11:409-418.

[48] Simpson AECM. The cytochrome P450 4 (CYP4) family. Gen Pharmacol. 1997; 28:351-359.

[49] Nelson DR, Koymans L, Kamataki T, Stegeman JJ, Feyereisen R, et al. P450 superfamily: update on new sequences, gene mapping, accession numbers and nomenclature. Pharmacogenetics. 1996;6:1-42.

[50] Bass C, Field LM. Gene amplification and insecticides resistance. Pest manag Sci. 2011;67: 886-890.

[51] Singh SP, Coronella JA, Benes H, Cochrane BJ, Zimniak P. Catalytic function of Drosophila Melanogaster glutathione s-transferase DmGSTS1-1 (GST-2) in conjugation of lipid peroxidation end products. European J Biochem. 2001;268: 2912-2923.

[52] Ranson H, Rossiter L, Ortelli F, Jensen B, Wang X, et al. Identification of a novel class of insect glutathione s-transferases involved in resistance to DDT in the malaria vector Anopheles gambiae. Biochem J. 2001;359:295-304.

[53] Yamamoto K, Shigeoka Y, Aso Y, Banno Y, Kimura M, et al. Molecular and biochemical characterization of a Zeta-class glutathione s-transferase of the silkmoth. Pestic Biochem Physiol. 2009;94:30-35.

[54] Clark AG, Shamaan NA. Evidence that DDT dehydrochlorinase from the house fly is a glutathione Stransferase. Pesti Bioche Physiol. 1984;22:249-261.

[55] Hemingway J, Ranson H. Insecticide resistance in insect vectors of human disease. Annu Rev Entomol. 2000;45:371-391. 
[56] Lewis JB, Sawicki RM. Characterization of the resistant mechanism to diazinon, parathion and diazoxon in the organophosphorous resistant SKA strain of house flies (Musca domestica L.). Pestic Biochem Physiol. 1971;1:275-285.

[57] Huang HS, Hu NT, Yao YE, Wu CY, Chiang SW. Molecular cloning and heterologous expression of a glutathione S-transferase involved in insecticide resistance from the diamondback moth, Plutella xylostella. Insect Biochem Mol Biol. 1998;28:651-658.

[58] Zhang N, Liu J, Chen SN, Huang LH, Feng QL, Zheng SC. Expression profiles of glutathione Stransferase superfamily in Spodoptera litura tolerated to sublethal doses of chlorpyrifos. Insect Sci. 2016;23:675-687.

[59] Vontas JG, Small GJ, Hemingway J. Glutathione S-transferases as antioxidant defence agents confer pyrethroid resistance in Nilaparvata lugens. Biochem J. 2001;357:65-72.

[60] Vontas JG, Small GJ, Nikou DC, Ranson H, Hemingway J. Purification, molecular cloning and heterologous expression of a glutathione S-transferase involved in insecticide resistance from the rice brown planthopper, Nilaparvata lugens. Biochem J. 2002;362:329-337.

[61] Zhou L, Fang SM, Huang K, Yu QY , Zhang Z. Characterization of an epsilon-class glutathione Stransferase involved in tolerance in the silkworm larvae after long term exposure to insecticides. Ecotox Environ Safe. 2015;120:20-26.

[62] Han JB, Li GQ, Wan PJ, Zhu TT, Meng QW. Identification of glutathione S-transferase genes in Leptinotarsa decemlineataand their expression patterns under stress of three insecticides. Pestici Biochem Physiol. 2016;133:26-34.

[63] Kim BY, Jin BR. Molecular characterization of a venom acid phosphatase Acph-1-like protein from the Asiatic honeybee Apis cerana. J Asia-Pac Entomol. 2014;17:695-700.

[64] Hollander VP. Acid phosphatase. In: Boyer PD, editors. The Enzymes, 3rd edition. New York, Academic Press; 1971.p. 449-498.

[65] Oppenoorth FJ, Biochemistry and genetics of insecticide resistance. In: Kerkut GA, Gilbert LI, editors. Comprehensive Insect Physiology, Biochemistry and Pharmacology. Oxford, Pergamon Press;1985. p.731773.

[66] Bhawane GP, Bhanot RK. Alkaline and acid phosphatases of cockchafers Holotrichia fissa Brinske. Ind J Entomol. 1994;56:342-346.

[67] Zheng YZ, Lan WS, Qiao CL, Mulchandani A, Chen W, Decon tamination of vegetables sprayed with organophosphate pesticides by organophosphorus hydrolase and carboxylesterase (B1). Appl Biochem Biotechnol. 2007;136:233-241. 
[68] Li XZ, Liu YH. Diet influences the detoxification enzyme activity of Bactrocera tau (Walker) (Diptera: Tephritidae). Acta Entomol Sinica. 2007;50:989-995.

[69] Nollet F, Kools P, van Roy F. Phylogenetic analysis of the cadherin superfamily allows identification of six major subfamilies besides several solitary members. J Mol Biol. 2000;299:551-572.

[70] Yagi T, Takeichi M. Cadherin superfamily genes: functions, genomic organization, and neurologic diversity. Genes Dev. 2000;14:1169-1180.

[71] Angst BD, Marcozzi C, Magee Al: The cadherin superfamily:diversity in form and function. J Cell Sci. 2001;114:629-641.

[72] Wheelock MJ, Johnson KR. Cadherins as modulators of cellular phenotype. Annu Rev Cell Dev Biol. 2003;19:207-235.

[73] Pardo-Lopez L, Soberon M, Bravo A. Bacillus thuringiensis insecticidal three domain Cry toxins: mode of action, insect resistance and consequences for crop protection. FEMS Microbiol Rev. 2013;37:3e22.

[74] Pigott CR, Ellar DJ. Role of receptors in Bacillus thuringiensis crystal toxin activity. Microbiol Mol Biol Rev. 2007;71:255-281.

[75] Gahan LJ, Gould F, Heckel DG. Identification of a gene associated with Bt resistance in Heliothis virescens. Sci. 2001;293:857-860.

[76] Nagamatsu Y, Toda S, Koike T, Miyoshi Y, Shigematsu S, Kogure M. Cloning, sequencing, and expression of the Bombyx mori receptor for Bacillus thuringiensis insecticidal CrylA(a) toxin. Biosci Biotechnol Biochem. 1998;62:727-734.

[77] Nagamatsu Y, Koike T, Sasaki K, Yoshimoto A, Furukawa Y. The cadherin-like protein is essential to specificity determination and cytotoxic action of the Bacillus thuringiensis insecticidal CrylAa toxin. FEBS Lett. 1999;460:385-390.

[78] Tabashnik BE, Cushing NL, Finson N, Johnson MW. Field development of resistance to Bacillus thuringiensis in diamondback moth (Lepidoptera: Plutellidae). J Econ Entomol. 1990;83:1671-1676.

[79] Tabashnik BE, Liu YB, Malvar T, Heckel DG, Masson L, Ballester V, et al. Global variation in the genetic and biochemical basis of diamondback moth resistance to Bacillus thuringiensis. Proc Natl Acad Sci USA. 1997;94:12780-12785.

[80] Park Y, Herrero S and Kim Y. A single type of cadherin is involved in Bacillus thuringiensis toxicity in Plutella xylostella.Insect Molecular Biology. 2015; 24: 624-633.

[81] Vadlamudi RK, Ji TH, Bulla LA. A specific binding protein from Manduca sexta for the insecticidal toxin of Bacillus thuringiensis subsp, Berliner. J Biol Chem. 1993;268:12334-12340. 
[82] Vadlamudi RK, Weber E, Ji I, Ji TH, Bulla LA. Cloning and expression of a receptor for an insecticidal toxin of Bacillus thuringiensis. J Biol Chem. 1995;270: 5490-5494.

[83] Jin JX, Jin DC, Li WH., Ye ZC, Zhou YH. Expression differences of resistance -related genes induced by cycloxaprid using qRT-PCR in the female adult of Sogatella furcifera (Horváth) (Hemiptera: Delphacidae)[J]. J Econ Entomol.2017;110:1785-1793.

[84] Zhuang YL, Shen JL. A method for monitoring of resistance to buprofezin in the brown planthopper. J Nanjing Agr Uni. 2000;23:114-117.

[85] Su JY, Wang ZW, Zhang K, Tian XR, Yin YQ, Zhao XQ, Shen AD, Gao CF. Status of insecticide resistance of the whitebacked planthopper, Sogatella furcifera (Hemiptera: Delphacidae). Fla Entomol. 2013;96:948956.

[86] Tang QY, Zhang CX. Data processing system (DPS) software with experimental design, statistical analysis and data mining developed for use in entomological research. Insect Sci. 2013;20:254-260.

[87] Grabherr MG, Haas BJ, Yassour M, Levin JZ, Thompson DA, Amit I, et al. Full-length transcriptome assembly from RNA-Seq data without a reference genome. Nature Biotechnol. 2011;29:644-652.

[88] Li B, Dewey CN. RSEM: accurate transcript quantification from RNA-Seq data with or without a reference genome. BMC Bioinformatics. 2011;doi:10.1186/1471-2105-12-323.

\section{Tables}

Table 1 The RNA quality evaluation of $S$. furcifera samples treated with cycloxaprid (HYFA) and the untreated (CKFA)

\begin{tabular}{llllll} 
Sample) & $\begin{array}{l}\text { Concentration } \\
(\mathrm{ng} / \mu \mathrm{l})\end{array}$ & $\begin{array}{l}\text { Volume } \\
(\mu \mathrm{l})\end{array}$ & $\begin{array}{l}\text { Quality }) \\
(\mu \mathrm{g})\end{array}$ & OD260/280 & RIN value \\
\hline HYFA1 & 770 & 39 & 30.03 & 2.005 & 7.3 \\
\hline HYFA2 & 536 & 39 & 20.9 & 1.971 & 7.2 \\
\hline HYFA3 & 514 & 38 & 19.53 & 1.962 & 8.8 \\
\hline CKFA1 & 826 & 38 & 31.39 & 1.986 & 7.2 \\
\hline CKFA2 & 688 & 38 & 26.14 & 2 & 7.2 \\
\hline CKFA3 & 640 & 38 & 24.32 & 1.976 & 7.1
\end{tabular}

Table 2 The quality analysis of transcriptome data 


\begin{tabular}{llllllll} 
Sample & $\begin{array}{l}\text { Raw } \\
\text { Reads }\end{array}$ & $\begin{array}{l}\text { Clean } \\
\text { Reads }\end{array}$ & $\begin{array}{l}\text { Clean } \\
\text { Bases }\end{array}$ & Error(\%) & Q20(\%) & Q30(\%) & $\begin{array}{l}\text { GC } \\
\text { Content(\%) }\end{array}$ \\
\hline HYFA1 & 48378522 & 46420430 & $6.96 \mathrm{G}$ & 0.02 & 96.24 & 91.5 & 36.53 \\
\hline HYFA2 & 47283654 & 45483546 & $6.82 \mathrm{G}$ & 0.02 & 96.42 & 91.69 & 34.89 \\
\hline HYFA3 & 47880270 & 45899152 & $6.88 \mathrm{G}$ & 0.02 & 96.23 & 91.44 & 38.66 \\
\hline CKFA1 & 45184564 & 42395408 & $6.36 \mathrm{G}$ & 0.02 & 96.62 & 91.98 & 36.04 \\
\hline CKFA2 & 45098544 & 42261462 & $6.34 \mathrm{G}$ & 0.02 & 96.44 & 91.6 & 35.35 \\
\hline CKFA3 & 45484342 & 42830940 & $6.42 \mathrm{G}$ & 0.02 & 96.68 & 92.05 & 35.66
\end{tabular}

Table 3 The data analysis of transcripts and unigenes in S. furcifera transcriptome treated with cycloxaprid

\begin{tabular}{|c|c|c|c|c|c|c|c|c|}
\hline & transcripts & & & & Unigenes & & & \\
\hline \multirow[t]{2}{*}{$\begin{array}{l}\text { length } \\
\text { interval }\end{array}$} & 200-500bp & $\begin{array}{l}500- \\
1 \mathrm{kbp}\end{array}$ & $\begin{array}{l}1 \mathrm{k}- \\
2 \mathrm{kbp}\end{array}$ & $>2 \mathrm{kbp}$ & $\begin{array}{l}200- \\
500 \mathrm{bp}\end{array}$ & $\begin{array}{l}500- \\
1 \mathrm{kbp}\end{array}$ & $\begin{array}{l}1 \mathrm{k}- \\
2 \mathrm{kbp}\end{array}$ & $>2 \mathrm{kbp}$ \\
\hline & 102129 & 29696 & 21527 & 21498 & 88679 & 20109 & 11915 & 10898 \\
\hline Total Number & 174850 & & & & 131601 & & & \\
\hline mean length & 903 & & & & 720 & & & \\
\hline N50 & 1895 & & & & 1412 & & & \\
\hline N90 & 308 & & & & 263 & & & \\
\hline $\begin{array}{l}\text { total } \\
\text { nucleotides }\end{array}$ & 157906456 & & & & 94739951 & & & \\
\hline
\end{tabular}

Table 4 Unigenes functional annotation by Nr, GO, KOG and KEGG, etc 


\begin{tabular}{lll} 
& Number of Unigenes & Percentage (\%) \\
\hline Annotated in NR & 26204 & 19.91 \\
\hline Annotated in NT & 15128 & 11.49 \\
\hline Annotated in KO & 11445 & 8.69 \\
\hline Annotated in SwissProt & 23028 & 17.49 \\
\hline Annotated in PFAM & 26899 & 20.43 \\
\hline Annotated in GO & 27079 & 20.57 \\
\hline Annotated in KOG & 15477 & 11.76 \\
\hline Annotated in all Databases & 4793 & 3.64 \\
\hline Annotated in at least one Database & 38534 & 29.28 \\
\hline Total Unigenes & 131601 & 100
\end{tabular}

Table 5 The primers for valication to the transcriptome treated by cycloxaprid 


\begin{tabular}{|c|c|c|c|}
\hline Name & & Sequence & Product size $\otimes b p \rrbracket$ \\
\hline 18SrRNA & Forward》 & GCCCCGTAATCGGAATGAGT & 205 \\
\hline Reference $\mathrm{g}$ & & & \\
\hline & Reverse $\rrbracket$ & GACAAGACGTCCCGCAAAAC & \\
\hline c74469_g1 & Forward》 & CTACTCGGCCTACCCGTACT & 157 \\
\hline & Reverse $\rrbracket$ & CGAAGCTATTGACGGTCGGA & \\
\hline c76759_g1 & Forward》 & TGTATGAACGTCGCAAGGCT & 96 \\
\hline & Reverse】 & AGCGCCTATATTCTTCCCGC & \\
\hline c68340_g1 & Forward》 & GCGAATTGGTCATACCACGC & 143 \\
\hline & Reverse】 & AGCCTGACGTCAATCAAGGG & \\
\hline c50811_g1 & Forward》 & CCGTCGTCTTCTTCCTGTAG & 68 \\
\hline & Reverse $\rrbracket$ & CGTCTCCTTCTTCGTGTTCC & \\
\hline c72913_g3 & Forward》 & CTGGTGTTATTAGTGACGGTTGTAG & 228 \\
\hline & Reverse $\rrbracket$ & TAGGAGTGCTGGCGAGAGG & \\
\hline c82227_g1 & Forward》 & AAGGAGGAGCAGGCAGAG & 225 \\
\hline & Reverse $\rrbracket$ & AGTGGCGAATGTTGGAAGG & \\
\hline c72647_g3 & Forward》 & GCCTTCCACCTACCGACATC & 247 \\
\hline & 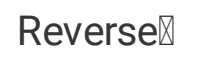 & TССТСTCACAACTGCCATCATC & \\
\hline c82813_g1 & Forward》 & СTTCTCCGAGGCATCAATC & 54 \\
\hline & 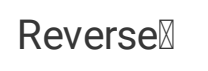 & GGACTCAGATAGCACATACG & \\
\hline c72170_g1 & Forward》 & CCATATTCTCAATGCTGCCTCTCAAG & 232 \\
\hline & Reverse $\rrbracket$ & TCATCCGTATCCATCGCCATCATC & \\
\hline c83438_g1 & Forward》 & ATCCTTGGTGTTGGCTACGG & 100 \\
\hline & 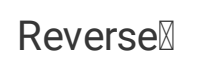 & TGTATATTGCGCAGGGCCAA & \\
\hline c79766_g1 & Forward》 & CTAGCAGTCTACGCCGAAGG & 77 \\
\hline & Reverse $\mathbb{Z}$ & AAGCCCATGCCTTTGCCTAT & \\
\hline c79304_g1 & Forward》 & GTAGGCGAGTACGTTAGGCG & 118 \\
\hline & 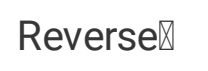 & GACCCCATCCTGAGCCAAAT & \\
\hline c76099_g1 & Forward》 & GGCTGCTGTGGAAATGGTTG & 184 \\
\hline & Reverse $\rrbracket$ & AGCATCAAAGGCAAGCAAGC & \\
\hline
\end{tabular}




\begin{tabular}{|c|c|c|c|}
\hline c70633_g2 & Forward》 & CTCAGTGCCATGCCACCATA & 107 \\
\hline & Reverse $\rrbracket$ & CCCATGTATCGCAACCCTGT & \\
\hline \multirow[t]{2}{*}{ c67652_g2 } & Forward $\rrbracket$ & TGATGCGGAGAAGGTATCGC & 172 \\
\hline & Reverse $\rrbracket$ & СTСАCССTCTCGGACTGGTA & \\
\hline \multirow[t]{2}{*}{ c62218_g1 } & Forward $\rrbracket$ & CATGTGCAAGGCATTGTGCT & 155 \\
\hline & Reverse $\rrbracket$ & AGCTGCGTATTCAGTGCCAT & \\
\hline \multirow[t]{2}{*}{ c45748_g1 } & Forward $\rrbracket$ & AGGAAGCCGTACCAAATCCA & 231 \\
\hline & Reverse $\rrbracket$ & GGGGTAGCACTACACCCAGT & \\
\hline c43029_g1 & Forward $\rrbracket$ & AAGGGAAGGAAGAGCATGGC & 159 \\
\hline
\end{tabular}

Table 6 The validation to the transcriptsome of $S$. furcifera treated by cycloxaprid in qRT-PCR 
Gene ID Transcriptsome

qRT-

Consistency

PCR

\begin{tabular}{|c|c|c|c|c|c|c|c|}
\hline & $\begin{array}{l}\text { XDFA_ } \\
\text { readcount }\end{array}$ & $\begin{array}{l}\text { CKFA_ } \\
\text { readcount }\end{array}$ & $\begin{array}{l}\text { log2Fold } \\
\text { Change }\end{array}$ & $\begin{array}{l}\text { The } \\
\text { mean } \\
\text { Ct of } \\
\text { XDFA }\end{array}$ & $\begin{array}{l}\text { The } \\
\text { mean } \\
\text { Ct of } \\
\text { CKFA }\end{array}$ & $\begin{array}{l}\text { F-value } \\
(2-\triangle \triangle \mathrm{Ct})\end{array}$ & \\
\hline C43029_g1 & 76.02 & 166.78 & -1.13 & 17.79 & 16.14 & 0.32 & Yes \\
\hline C45748_g1 & 126.47 & 10.22 & 3.63 & 17.82 & 17.60 & 0.86 & No \\
\hline C50811_g1 & 0.00 & 9.67 & - & 24.28 & 24.50 & 1.16 & No \\
\hline C67652_g2 & 68.47 & 206.99 & -1.60 & 18.61 & 17.03 & 0.34 & Yes \\
\hline C68340_g1 & 2002.36 & 0.00 & - & 8.92 & 25.91 & 130384.02 & Yes \\
\hline C70633_g2 & 0.98 & 102.63 & -6.70 & 23.73 & 18.95 & 0.04 & Yes \\
\hline C72170_g1 & 8.88 & 102.26 & -3.53 & 20.40 & 16.49 & 0.07 & Yes \\
\hline c74469_g1 & 1407.52 & 3557.59 & -1.34 & 10.89 & 9.91 & 0.50 & Yes \\
\hline C72647_g3 & 456.84 & 160.97 & 1.50 & 14.91 & 15.33 & 1.35 & Yes \\
\hline C72913_g3 & 4289.74 & 2097.39 & 4.61 & 10.99 & 11.82 & 1.77 & Yes \\
\hline c76099_g1 & 0.00 & 118.31 & - & 22.41 & 22.06 & 0.78 & Yes \\
\hline C79304_g1 & 457.23 & 156.39 & 1.55 & 11.97 & 11.90 & 0.95 & No \\
\hline C79766_g1 & 243.06 & 114.95 & 1.08 & 16.07 & 16.57 & 1.41 & Yes \\
\hline C82227_g1 & 0.00 & 40.41 & - & 23.02 & 22.79 & 0.85 & Yes \\
\hline C83438_g1 & 0.00 & 119.94 & - & 24.12 & 24.67 & 1.47 & No \\
\hline C76759_g1 & 30.80 & 2057.69 & -6.06 & 11.79 & 10.39 & 0.38 & Yes \\
\hline C62218_g1 & 1.99 & 517.62 & -8.02 & 20.65 & 11.57 & 0.00 & Yes \\
\hline C82813_g1 & 0.00 & 43.43 & - & 16.21 & 15.19 & 0.49 & Yes \\
\hline
\end{tabular}

Table 7 The statistic information for special unigenes associated with insecticide resistance 
Resistance-related gene Category

Metabolic

Resistance

$\begin{array}{ll}\text { Unigenes } & \text { Maximum } \\ \text { Number } & \begin{array}{l}\text { Unigenes } \\ \text { length }\end{array}\end{array}$

Cytochrome P450

237

48

Glutathione -s

transferase

(GST)

Carboxylesterase

19

6786

270

2803

(CarE)

\begin{tabular}{|c|c|c|c|c|c|}
\hline & $\begin{array}{l}\text { Acid phosphatase } \\
\text { (ACP) }\end{array}$ & 91 & 26413 & 207 & 3146 \\
\hline \multirow[t]{7}{*}{ Target Resistance } & $\begin{array}{l}\text { Nicotinic } \\
\text { Acetylcholine } \\
\text { Receptor } \\
\text { (nAChRs) }\end{array}$ & 17 & 6489 & 222 & 1654 \\
\hline & $\begin{array}{l}\text { Y-aminobutyric acid } \\
\text { receptor } \\
\text { (GABA receptor) }\end{array}$ & 37 & 8961 & 211 & 2810 \\
\hline & sodium channel & 99 & 9011 & 202 & 1243 \\
\hline & $\begin{array}{l}\text { Acetylcholinesterase } \\
\text { (AChE) }\end{array}$ & 50 & 5143 & 209 & 1838 \\
\hline & ATP synthase & 236 & 8813 & 201 & 1319 \\
\hline & $\begin{array}{l}\text { Cytochrome b } \\
\text { (Cyt b) }\end{array}$ & 187 & 12444 & 201 & 1566 \\
\hline & Cadherin & 76 & 12444 & 205 & 1905 \\
\hline
\end{tabular}

Table 8 Identification of DEGs associated with insecticide resistance 


\begin{tabular}{lll} 
Gene function & Gene length & pval \\
\hline Cytochrome P450 & 1917 & $1.12 \mathrm{E}-17$ \\
\hline & 2381 & $1.74 \mathrm{E}-05$ \\
\hline Glutathione S-transferase(GST) & 1523 & $2.30 \mathrm{E}-09$ \\
\hline & 977 & $2.14 \mathrm{E}-05$ \\
\hline Acid Phosphatase(ACP) & 896 & $2.34 \mathrm{E}-08$ \\
\hline Cadherin & 502 & $2.74 \mathrm{E}-06$
\end{tabular}

Figures 


\section{Length Distribution}

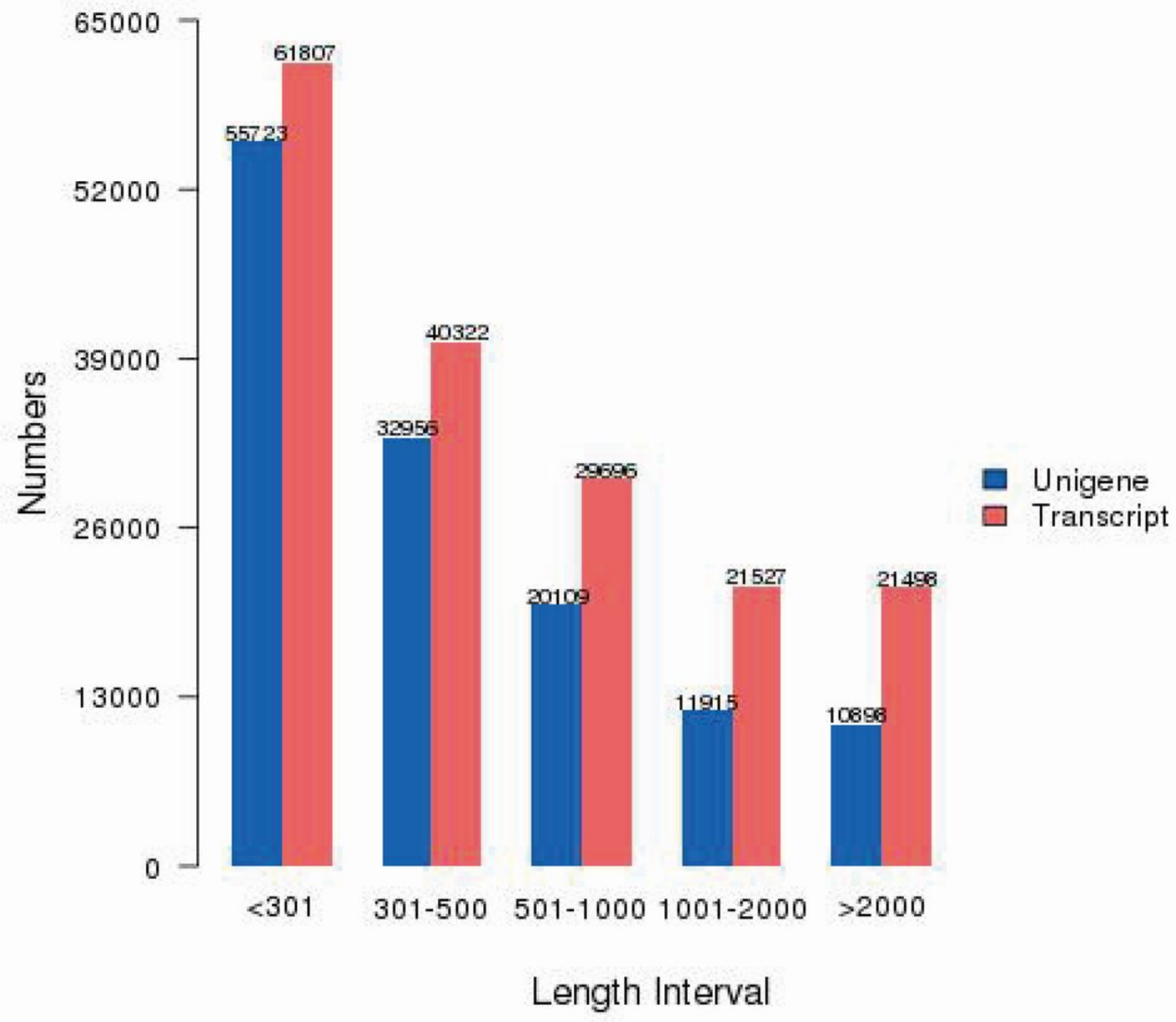

Figure 1

The length distribution of transcripts and unigenes of Sogatella furcifera. The $x$ axis shows the lengths of transcripts and unigenes and the $y$ axis shows the number of transcripts and unigenes. 


\section{Species classification}

$\square$ Diaphorina citri
- Bactrocera cucurbitae
$\square$ other

B

E-value Distribution

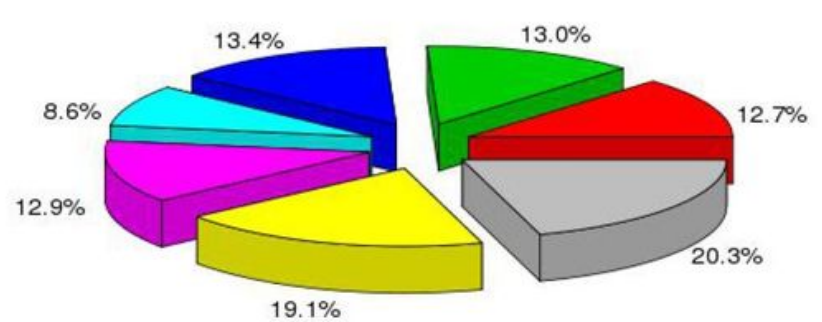

므 ${ }_{0 \sim 1 \mathrm{e}-100}$

- $1 \mathrm{e}-100 \sim 1 \mathrm{e}-60$

므 $1 e-45 \sim 1 e-30$
마 $1 e-30 \sim 1 e-15$
ㅁ $1 e-15 \sim 1 e-5$

C

Similarity Distribution

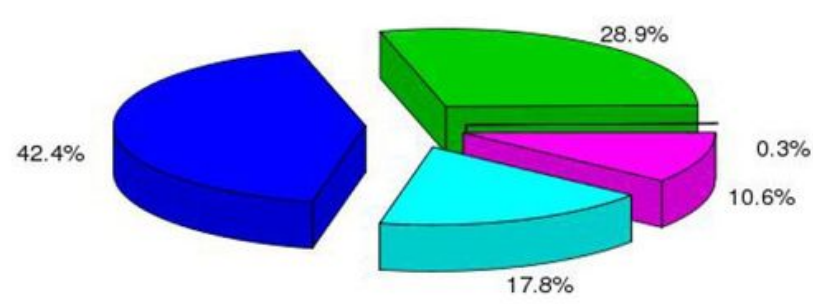

- $18 \% \sim 40 \%$ 므 $40 \% \sim 60 \%$
마 $80 \% \sim 95 \%$

a $95 \% \sim 100 \%$

\section{Figure 2}

Species distribution $\square E-v a l u e ~ d i s t r i b u t i o n$ and similarity distribution of unigene against the NCBI. A-Species distribution of unigene BLASTX results against the NCBI-NR protein database. B-E-value distribution of unigene against the NCBI-NR protein database. C-similarity istribution of unigene against the NCBI-NR protein database. 


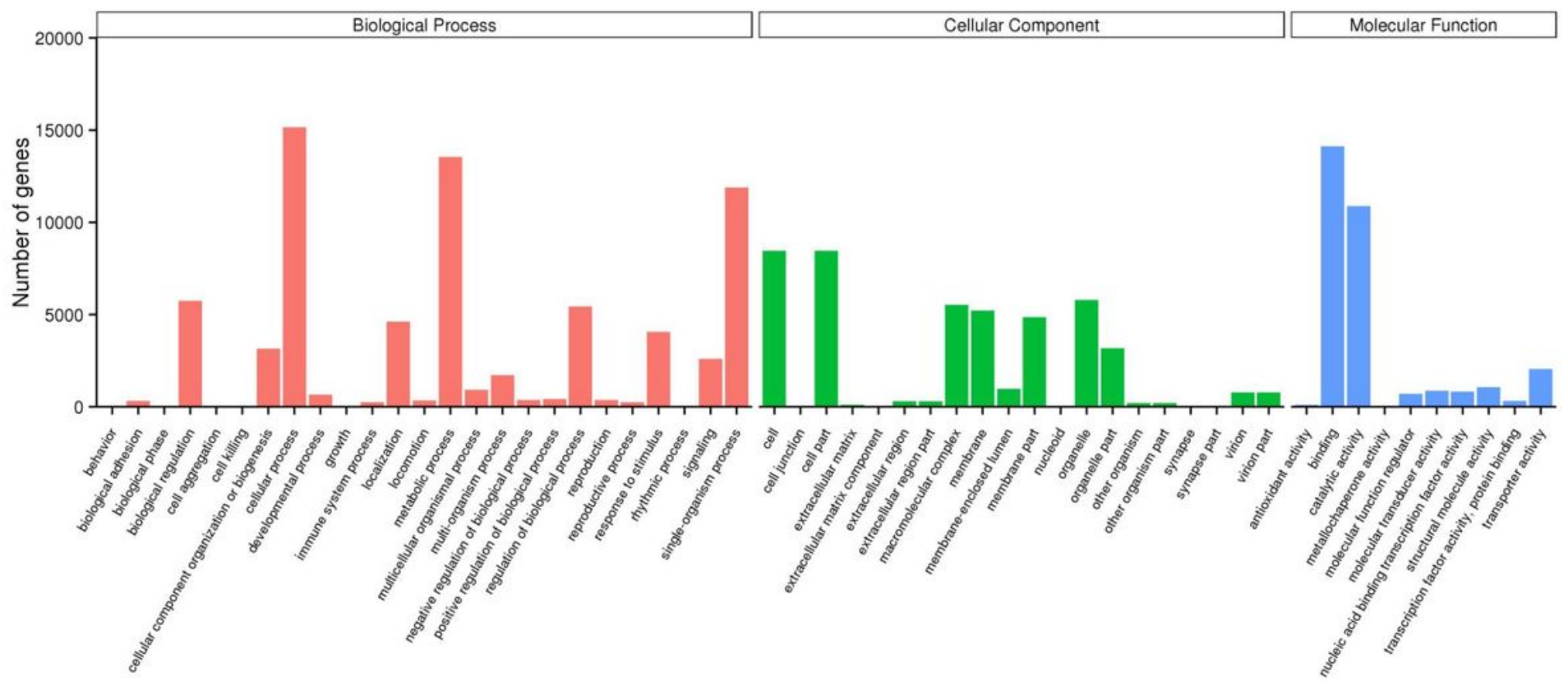

\section{Figure 3}

Comparison of GO classification of putative functions of genes from cycloxaprid treatment and no treatment of $\mathrm{S}$. furcifera samples. The $\mathrm{x}$ axis shows subgroups of molecular functions from $\mathrm{GO}$ classification and the $y$ axis shows the number of the matched unigene sequences.

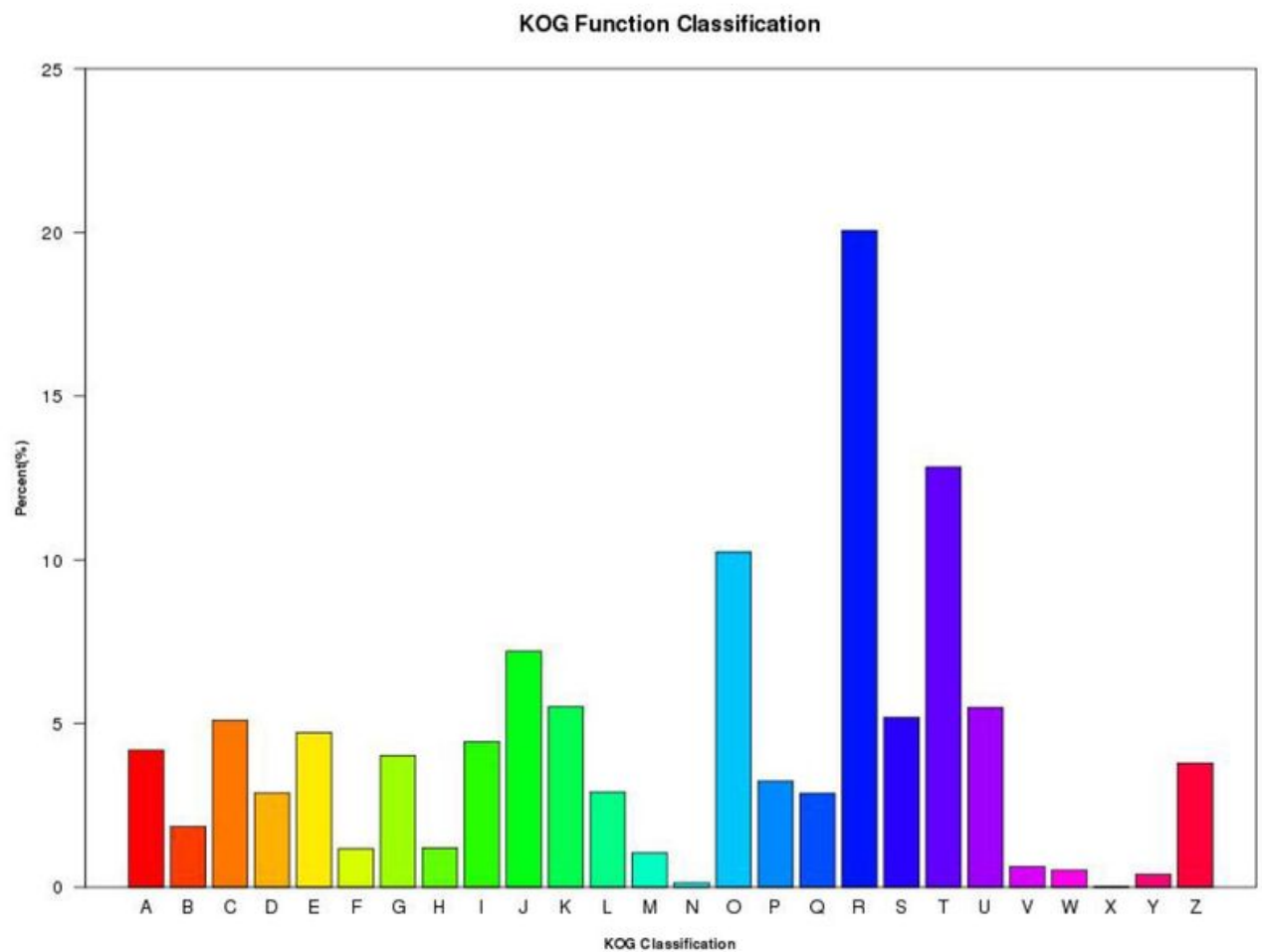

(A) RNA processing and modification

(B) Chromatin structure and dynamics

(C) Energy production and conversion

(D) Cell cycle control, cell division, chromosome partitioning

(E) Amino acid transport and metabolism

(F) Nucleotide transport and metabolism

(G) Carbohydrate transport and metabolism

(H) Coenzyme transport and metabolism

(I) Lipid transport and metabolism

(J) Translation, ribosomal structure and biogenesis

(K) Transcription

(L) Replication, recombination and repair

(M) Cell wall/membrane/envelope biogenesis

(N) Cell motility

(O) Posttranslational modification, protein turnover, chaperones (P) Inorganic ion transport and metabolism

(Q) Secondary metabolites biosynthesis, transport and catabolism

(R) General function prediction only

(S) Function unknown

(T) Signal transduction mechanisms

(U) Intracellular trafficking, secretion, and vesicular transport

(V) Defense mechanisms

(W) Extracellular structures

(X) Unamed protein

(Y) Nuclear structure

(Z) Cytoskeleton

\section{Figure 4}


The detail function of genes in KOG database. The $x$ axis shows the groups name in KOG and the percentage of unigenes annotated in a group account to the total unigenes annotated in KOG database.

\section{KEGG Classification}

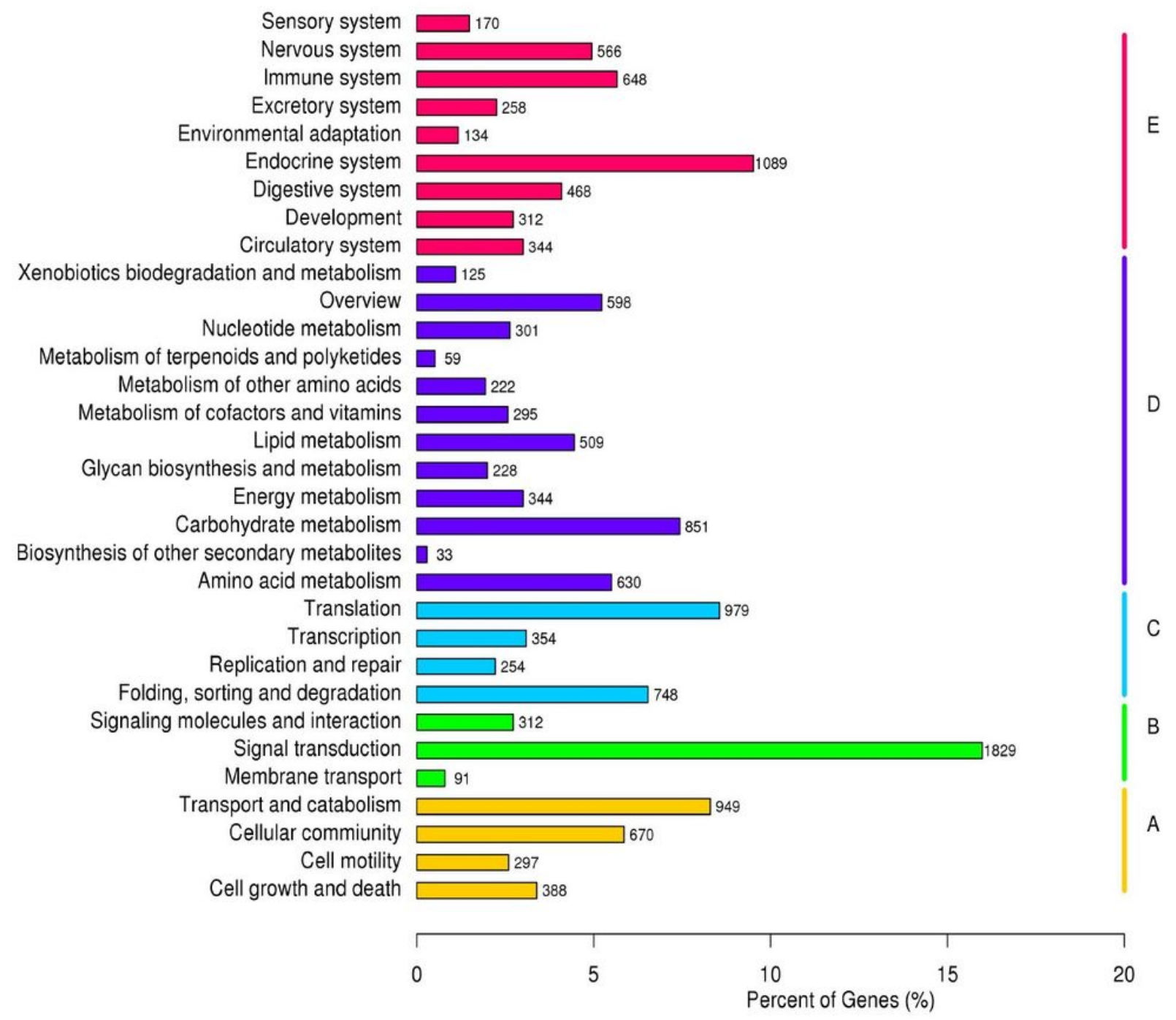

\section{Figure 5}

Comparison of KEGG pathway distributions. The $x$ axis shows the percentage of unigenes annotated in a group account to the total unigenes annotated in KOG database.the y axis shows the name of KEGG pathway. The genes according to KEGG metabolic pathway involved was divided into five branches: ACellular Processes; B-Environmental Information Processing; C-Genetic Information Processing; DMetabolism; E-Organismal Systems. 
A

Total number of sequences examined

131601

Total size of examined sequences(bp)

94739951

Total number of identified SSRs

15868

Number of SSR containing sequences

13898

Number of sequences containing more than 1 SSR

1626

Number of SSRs present in compound formation

700

B

\section{Distribution of SSR Motifs}

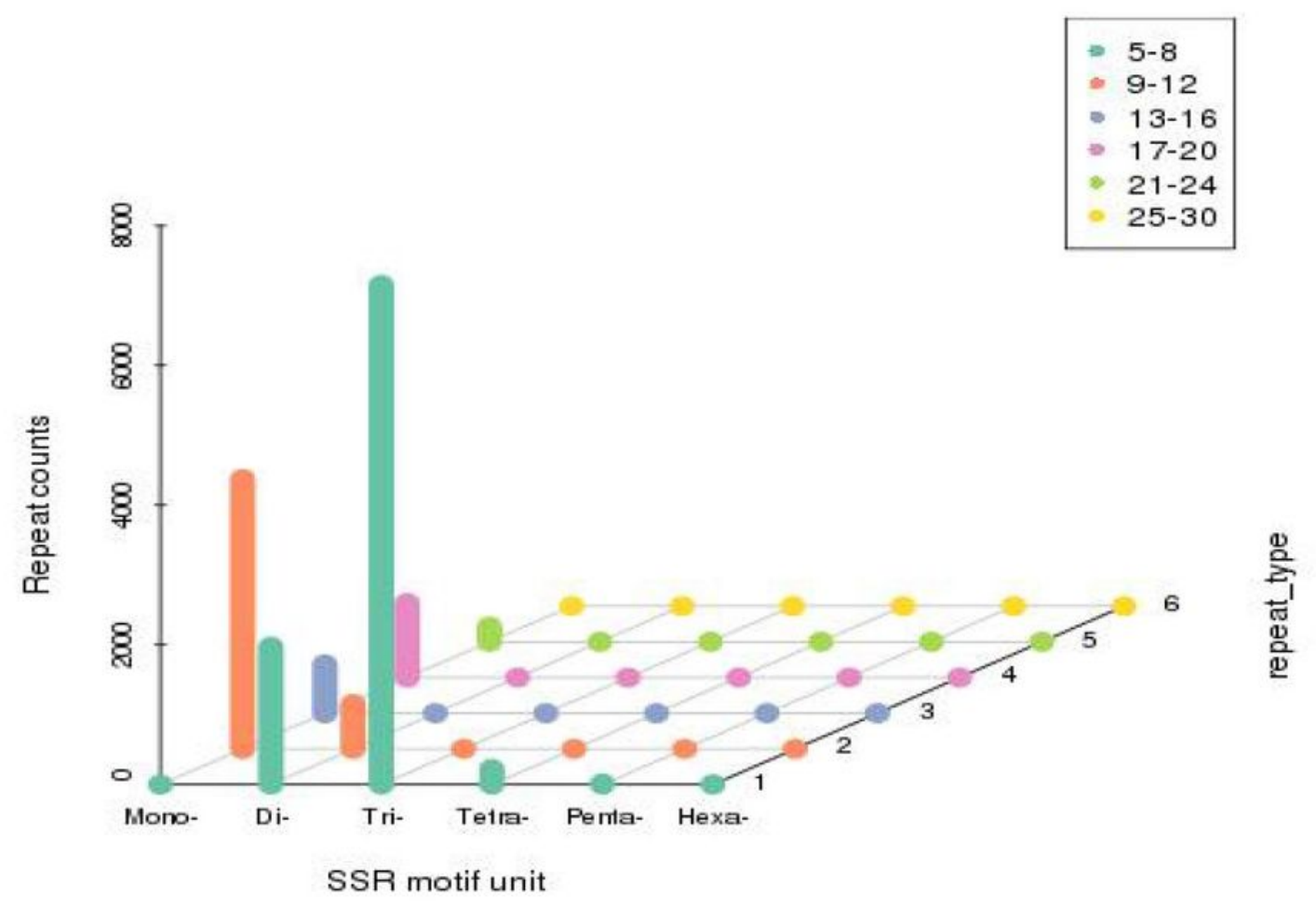

\section{Figure 6}

Distribution of simple sequence repeats motifs(SSR). The $x$ axis shows the SSR repeat type the $y$ axis shows the repeat counts. the $z$ axis shows the number of SSR. 


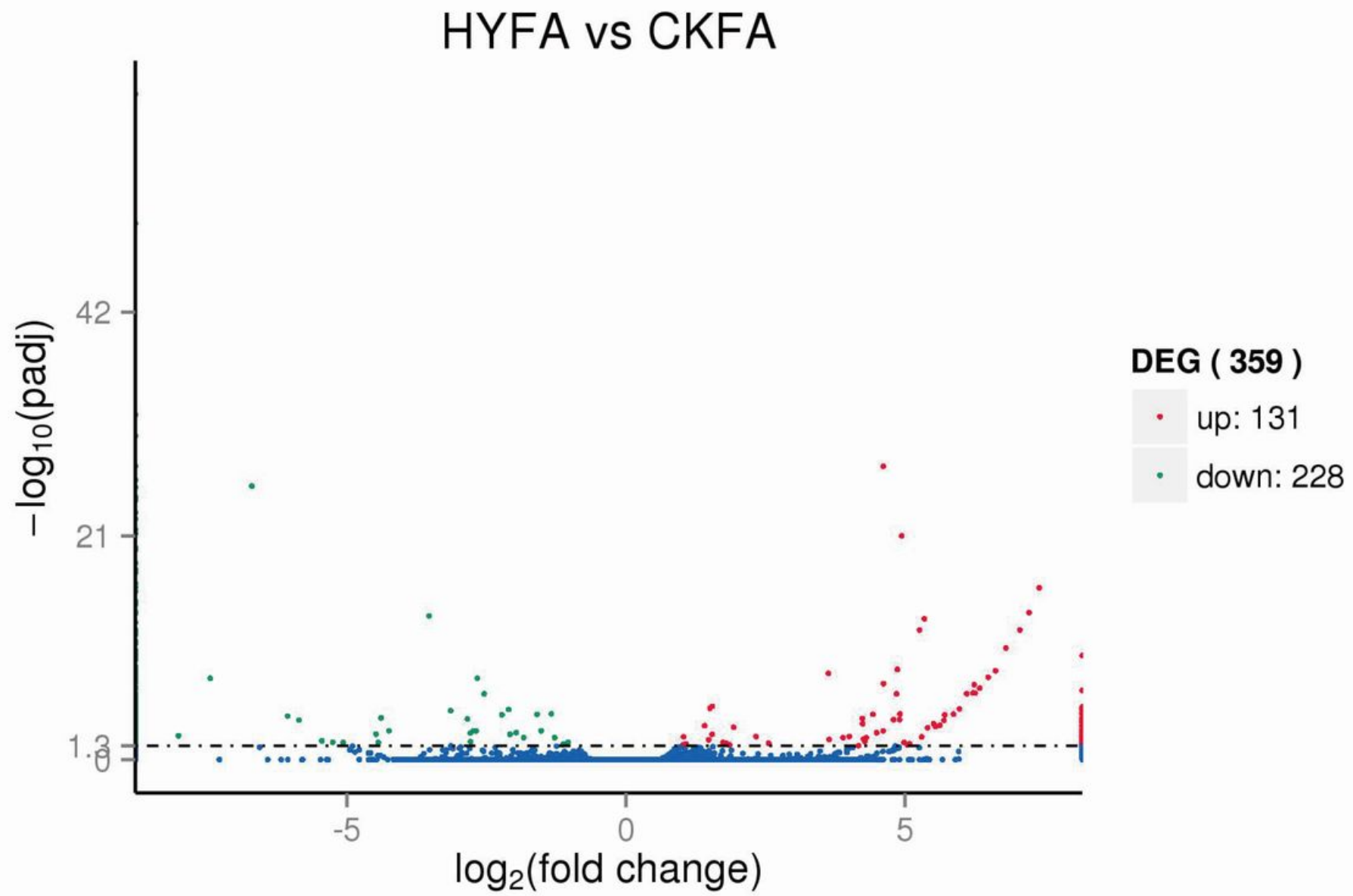

Figure 7

The volcanoplot of differentially expressed genes of S. Furcifera based on transcriptome.The red and green points represent genes up-regulated and down-regulated genes by the comparison between cycloxaprid treatment and no treatment of S. furcifera, respectively, the blue points represent genes that have no differences in regulation based on the criterion of FDR $<0.05$ and an absolute value of the log2(fold change) $>1$. HYFA represents the samples treated with cycloxaprid, LD $10=0.5823 \mathrm{mg} \cdot \mathrm{I}-1$ and CKFA represents the samples with no treatment. 


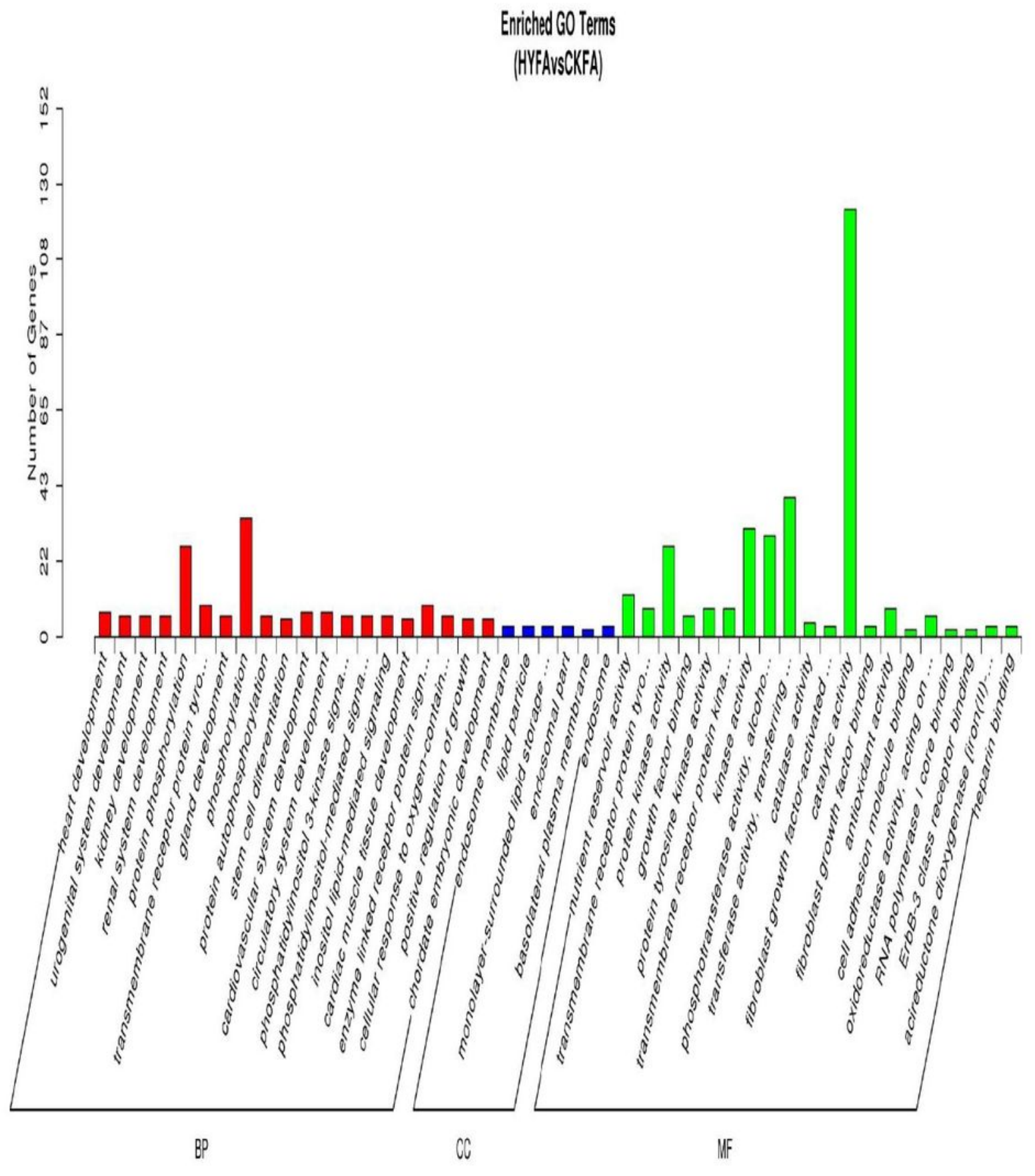

\section{Figure 8}

Distribution of the significantly up- and down-regulated unigenes in the enriched terms of GO classification. The $x$ axis shows the terms of GO classification, including (BP) Biological process. (MF) Molecular function. (CC) Cellular component. The y axis shows the number of genes eriched in a term. HYFA represents the samples treated with cycloxaprid, $\mathrm{LC} 10=0.58 \mathrm{mg} \cdot 1-1$ and CKFA represents the samples with no treatment. 




\section{B}

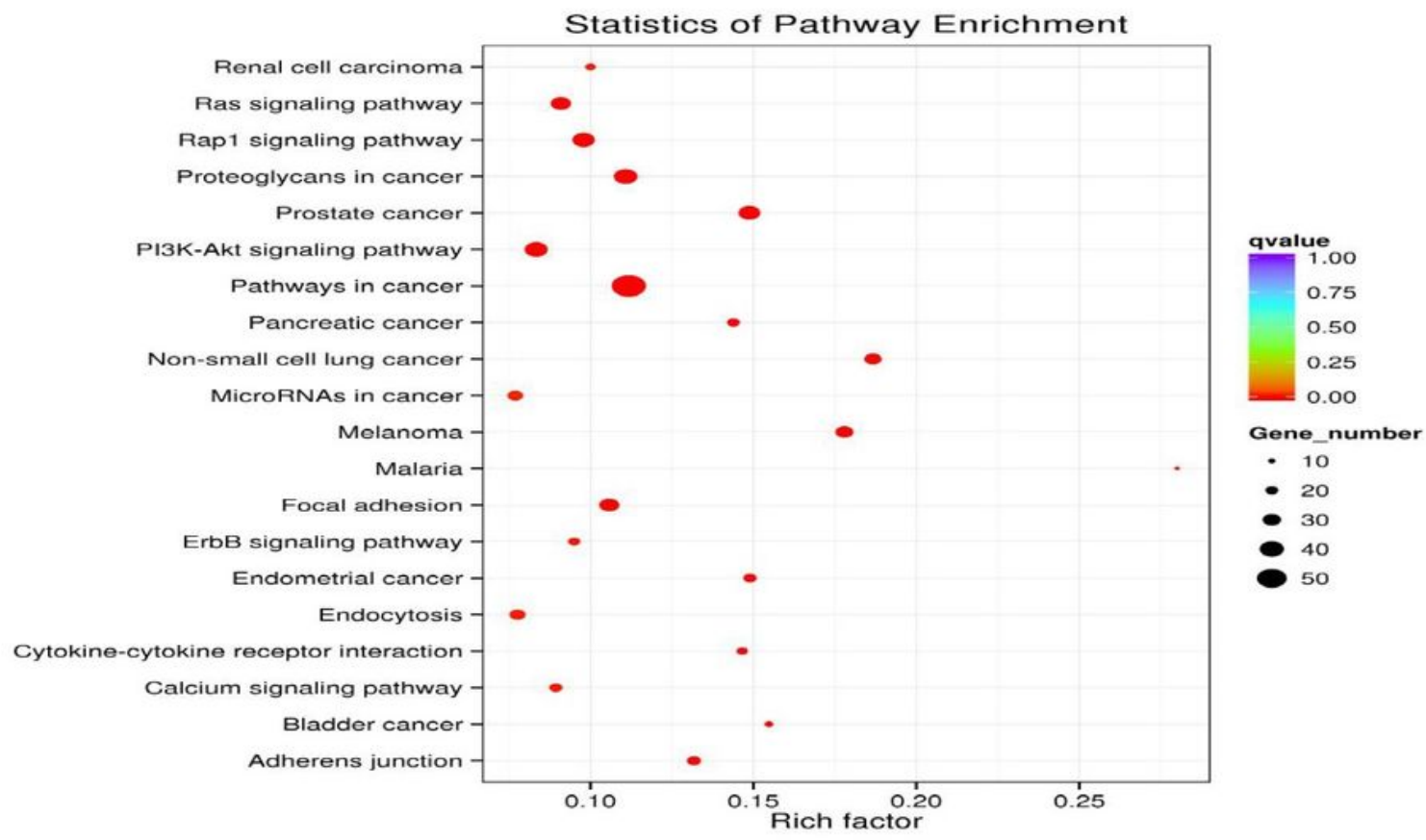

\section{Figure 9}

KEGG pathway distributions of S. furcifera differentially expressed genes. A-KEGG pathway distributions of the down-regulated genes. B-KEGG pathway distributions of the up-regulated genes. 